\title{
Structure and Lateral Organization of Phosphatidylinositol 4,5-bisphosphate
}

\author{
Luís Borges-Araújo ${ }^{1, *}$ and Fabio Fernandes ${ }^{1,2}$ \\ 1 iBB - Institute for Bioengineering and Biosciences, Instituto Superior Técnico, Universidade de Lisboa, \\ 1049-001 Lisbon, Portugal; fernandesf@tecnico.ulisboa.pt \\ 2 Department of Bioengineering, Instituto Superior Técnico, Universidade de Lisboa, 1049-001 Lisbon, Portugal \\ * Correspondence: lpborgesaraujo@tecnico.ulisboa.pt
}

Academic Editors: Luís M.S. Loura and Maria João Moreno

Received: 31 July 2020; Accepted: 23 August 2020; Published: 26 August 2020

check for updates

\begin{abstract}
Phosphatidylinositol 4,5-bisphosphate $\left(\mathrm{PI}(4,5) \mathrm{P}_{2}\right)$ is a minor but ubiquitous component of the inner leaflet of the plasma membrane of eukaryotic cells. However, due to its particular complex biophysical properties, it stands out from its neighboring lipids as one of the most important regulators of membrane-associated signaling events. Despite its very low steady-state concentration, $\mathrm{PI}(4,5) \mathrm{P}_{2}$ is able to engage in a multitude of simultaneous cellular functions that are temporally and spatially regulated through the presence of localized transient pools of $\mathrm{PI}(4,5) \mathrm{P}_{2}$ in the membrane. These pools are crucial for the recruitment, activation, and organization of signaling proteins and consequent regulation of downstream signaling. The present review showcases some of the most important PI(4,5)P2 molecular and biophysical properties as well as their impact on its membrane dynamics, lateral organization, and interactions with other biochemical partners.
\end{abstract}

Keywords: phosphoinositides; lipid domains; calcium-induced clustering

\section{Introduction}

The plasma membrane is a complex structure tasked with enclosing the cell and separating it from the surrounding environment. While biomembranes provide structure and define the boundaries of the cell, their dynamic biochemical and biophysical characteristics also allow them to regulate traffic and communication to and from the cytosol, organize reaction sequences, and promote cellular processes. These biophysical properties are defined not only by the intrinsic physical and chemical properties of the lipids, proteins, and other components but also by their complex set of interactions. This complexity holds the key to many key cellular processes. A lipid that stands out in the landscape of the eukaryotic plasma membrane is phosphatidylinositol 4,5-bisphosphate $\left(\mathrm{PI}(4,5) \mathrm{P}_{2}\right)$. $\mathrm{PI}(4,5) \mathrm{P}_{2}$ is the most abundant phosphoinositide in mammalian cells and is found primarily in the inner leaflet of the plasma membrane. It has also been found in endosomes, in the endoplasmic reticulum, and in the nucleus [1]. While its role as a source of secondary messengers during signaling events is known for decades [2], evidence has accumulated through time of its importance as an intact phospholipid for defining plasma membrane identity in eukaryotic cells. Due to its very large headgroup and multivalent negative charge, $\mathrm{PI}(4,5) \mathrm{P}_{2}$ acts almost like an electrostatic beacon, interacting specifically or non-specifically with several molecular entities such as membrane proteins, other lipids, cellular cations, etc. As a result of its particular biophysical properties, it is a major regulator of a wide spectrum of plasma membrane events, including cell adhesion and motility [3,4], ion channel transport $[5,6]$, vesicle endocytosis [7-11], and exocytosis [8,12-14] (Figure 1).

This wide-ranging reach of $\mathrm{PI}(4,5) \mathrm{P}_{2}$ as a critical functional lipid has made it an important research focus over the last decades in cell biology and more specifically in areas such as neuroscience, virology, and biophysics. In this review, we will focus on the physical, chemical, and structural 
properties of $\mathrm{PI}(4,5) \mathrm{P}_{2}$. The impact of these properties on membrane dynamics and interactions with $\mathrm{PI}(4,5) \mathrm{P}_{2}$ biochemical partners will also be described. We will give particular focus to $\mathrm{PI}(4,5) \mathrm{P}_{2}$ conformation dynamics, lateral organization, and the monodisperse $\mathrm{PI}(4,5) \mathrm{P}_{2}-\mathrm{PI}(4,5) \mathrm{P}_{2}$ nanodomain duality. As mentioned above, $\mathrm{PI}(4,5) \mathrm{P}_{2}$ is also found in the nuclear membrane, where it is thought to contribute to compartmentalization $[15,16]$, as well as on membraneless organelles within the nucleus $[15,16]$. However, this review will focus on the behavior and properties of $\operatorname{PI}(4,5) \mathrm{P}_{2}$ in the plasma membrane (PM) and PM mimicking membranes.

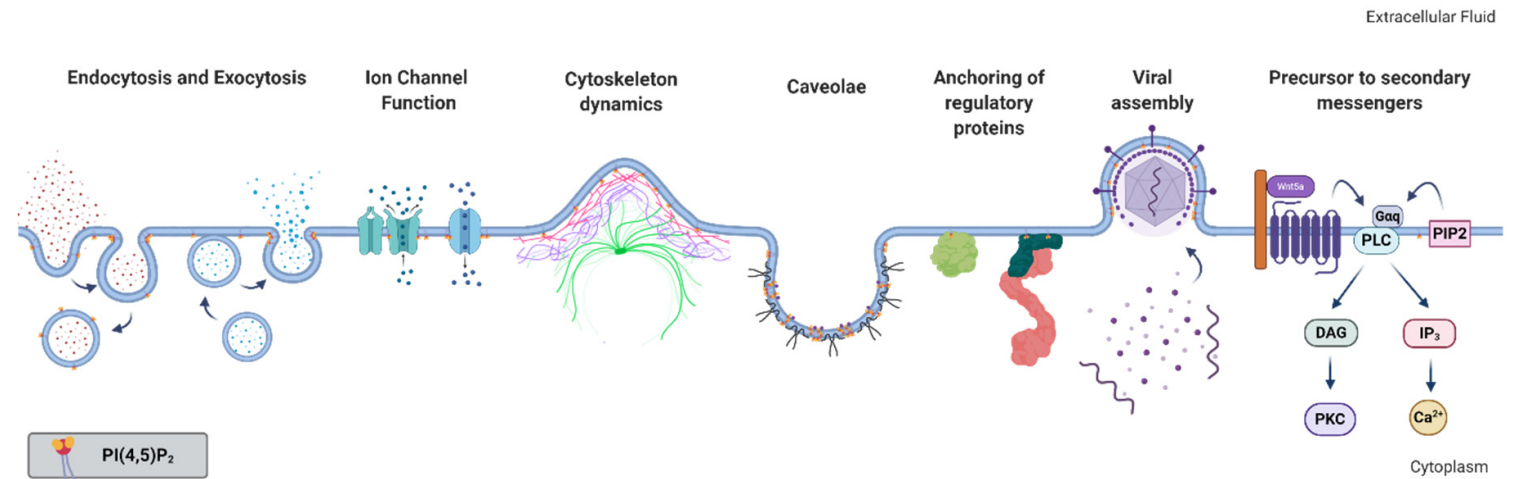

Figure 1. Membrane processes associated with or dependent on phosphatidylinositol 4,5-bisphosphate $\left(\mathrm{PI}(4,5) \mathrm{P}_{2}\right)$. Figure created with BioRender.com.

\section{The Phosphoinositide Family}

$\mathrm{PI}(4,5) \mathrm{P}_{2}$ is a member of the phosphoinositide (PI) lipid family. PIs are a small group of glycerophospholipids derived from phosphatidylinositol. These lipids consist of a characteristic inositol headgroup, which can undergo reversible phosphorylation and dephosphorylation, leading to the formation of seven distinct phosphorylated species. While the parent lipid phosphatidylinositol represents roughly $10 \%$ of total membrane phospholipids in the eukaryotic cell, the phosphorylated derivatives account only for around $2-3 \%$ [1], with $\mathrm{PI}(4) \mathrm{P}$ and $\mathrm{PI}(4,5) \mathrm{P}_{2}$ representing the bulk of these lipids [17]. Each of these seven species has a distinct subcellular distribution with predominant localization in subsets of membranes. Additionally, within a given membrane the localization of a specific PI can be heterogeneous. Many PIs are overall in low abundance in the membrane but they can be found at high local concentrations in membrane domains not readily detected by conventional techniques [3,17]. For a historical review on inositol lipids, see Irvine (2016) [18]. Over the last couple of decades, PIs have been found to be one of the most ubiquitous signaling entities in eukaryotic metabolism. Their reach extends from controlling organelle biology to regulating cellular growth. Due to this all-encompassing reach, they have also been linked to a number of human diseases. In fact, the inositide signaling pathway is considered a promising pharmaceutical target. For an excellent review on the major developments on PI cellular biology and their impact on disease, see Balla (2013) [3].

\section{3. $\mathrm{PI}(4,5) \mathrm{P}_{2}$ Structure}

\subsection{Headgroup Conformation}

The core PI $(4,5) \mathrm{P}_{2}$ structure descends from its "parent" lipid, phosphatidylinositol. At the core, it consists of a myo-inositol headgroup. There are 9 existing isomers of inositol but the myo-inositol isomer is the most commonly found in eukaryotic cells. In its most stable conformation, it assumes the chair conformation where every hydroxyl substituent is at the equatorial position except for the hydroxyl in the position 2 of the ring, which is in an axial position. The myo-inositol moiety is typically linked to the diacylglycerol (DAG) backbone via a phosphodiester bond in position 1 . This leaves the hydroxyl groups in positions 2 to 6 open. However, only positions 3,4 , and 5 can be enzymatically 
phosphorylated to yield the 7 phosphorylated PI species. $\mathrm{PI}(4,5) \mathrm{P}_{2}$ is the result of phosphorylation in positions 4 and 5 of the headgroup by specific kinases and phosphatases (Figure 2A).

A

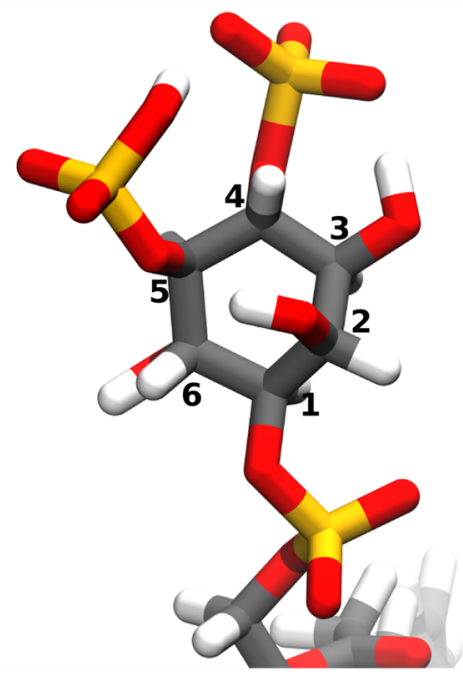

B

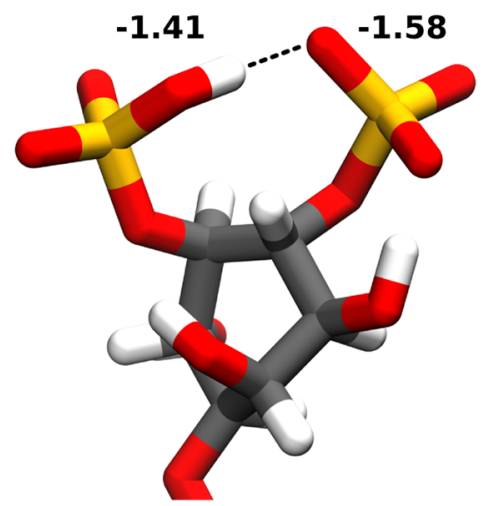

Figure 2. $\mathrm{PI}(4,5) \mathrm{P} 2$ headgroup features. The $\mathrm{PI}(4,5) \mathrm{P}_{2}$ headgroup consists of myo-inositol ring where every hydroxyl substituent is at the equatorial position except for the hydroxyl in the position 2 of the ring, which is in an axial position. In the case of PIP2, the hydroxyls in positions 4 and 5 are enzymatically phosphorylated. It is linked to the diacylglycerol (DAG) backbone via a phosphodiester bond in position 1 (A). At $\mathrm{pH}$ 7.0, one of the phosphodiester proton dissociates, and the one remaining is shared between the two vicinal phosphomonoester groups. In terms of potential charge this means that, at $\mathrm{pH} 7.0$, the charges would be -1.58 and -1.41 for the phosphomonoester groups at positions 4 and 5, respectively [19]. The lower charge of the 5-phosphomonoester group is attributed to a network of intramolecular hydrogen bonds that it is engaged in, which stabilize the proton (B). Carbon atoms are colored in grey, hydrogen in white, oxygen in red, and phosphorus in orange. Snapshots obtained from a simulation of a bilayer consisting of 95:5 mol ratio 1-palmitoyl-2-oleoyl-sn-glycero-3-phosphocholine (POPC): PI(4,5)P2, using the CHARMM36m forcefield run in GROMACS2019. Images were modeled using VMD.

In mammals, the majority of $\mathrm{PI}(4,5) \mathrm{P}_{2}$ in the plasma membrane is synthesized from $\mathrm{PI}(4) \mathrm{P}$ by type I phosphatidylinositol-4-phosphate 5-kinases (PIP5Ks) $(\alpha, \beta$, and $\gamma)$ [20]. Type II phosphatidylinositol 5-phosphate 4-kinase (PIP4K) $(\alpha, \beta$, and $\gamma)$ phosphorylate $\mathrm{PI}(5) \mathrm{P}_{2}$ to synthesize a quantitatively minor pool of $\mathrm{PI}(4,5) \mathrm{P}_{2}$ localized in the Golgi $[1,21,22]$. It can also be produced by the dephosphorylation of $\mathrm{PI}(3,4,5) \mathrm{P}_{3}$ catalyzed by phosphatase and tensin homolog protein (PTEN) and phosphatidylinositol 3,4,5-trisphosphate 3-phosphatase (TPIP) $(\alpha, \beta$, and $\gamma)[23,24]$. PI $(4,5) \mathrm{P}_{2}$ hydrolysis is controlled by specific 4'- or 5'-phosphatases or by phospholipase breakdown in response to various stimuli. Dephosphorylation by specific phosphatases (primarily 5'-phosphatases) controls $\mathrm{PI}(4,5) \mathrm{P}_{2}$ steady-state levels and controls the extent of its signaling. Additionally, cleavage by phospholipases, such as phospholipase C (PLC), control $\mathrm{PI}(4,5) \mathrm{P}_{2}$ levels and originate metabolites that propagate and amplify cellular signaling. $\mathrm{PI}(4,5) \mathrm{P}_{2}$ levels, in general, are the result of a complex interplay of many cellular enzymes. While $\mathrm{PI}(4,5) \mathrm{P}_{2}$ metabolism falls out of the scope of this review, more information can be found elsewhere $[3,25]$.

\subsection{Membrane Conformation Dynamics}

In terms of molecular structure when inserted into the membrane, there are surprisingly very few experimental studies probing $\mathrm{PI}(4,5) \mathrm{P}_{2}$ dynamics. Since the dynamics of phosphatidylinositol 
or of the mono-phosphorylated PI(4)P has been addressed to some extent, we can estimate some of $\mathrm{PI}(4,5) \mathrm{P}_{2}$ properties from the behavior of these closely related precursors. At the insertion depth of phosphatidylinositol and PI(4)P, when inserted into the membrane and in the absence of any interactions with other chemical partners, it is believed that the phosphodiester bond is located roughly at the same depth as the phosphodiester of phosphatidylcholine. Additionally, evidence points out that the phosphodiester bond remains roughly parallel when compared to the membrane normal [26-29].

$\mathrm{PI}(4,5) \mathrm{P}_{2}$ headgroup tilt seems to be significantly impacted by phosphorylation. For the case of phosphatidylinositol, the headgroup is roughly perpendicular to the membrane plane, with the C4 hydroxyl as the most exposed to the water layer despite a slight tilt being observed arising from an intramolecular hydrogen bond established between the C2 hydroxyl and the pro-R-oxygen of the phosphodiester phosphate [26-28,30]. This is the result of the glyceryl-phosphate-inositol link being always very close to a trans, trans, trans, gauche-conformation, which brings the two hydrogen bond partners together. Interestingly, the formation of this hydrogen bond appears to be crucial for the recognition by PLC, however, it is not yet clear if it is formed when phosphatidylinositol is aggregated [27]. In the case of PI(4)P, the headgroup tilt is more significant [26,28,29], and authors suggest it might be also due to the establishment of electrostatic interactions between the negatively charged phosphate and the positively charged choline headgroups from the neighboring lipids. For PI(4)P, due to this more significant tilt, the C5 hydroxyl is the most accessible to the water layer.

In a Variable Angle Sample Spinning NMR study [29], PI(4,5) $\mathrm{P}_{2}$ membrane conformation was studied in a membrane-like environment consisting of neutral alkyl-poly(ethylene)glycol and long-chain alcohols. All possible conformations obtained showed a much more pronounced headgroup tilt for $\mathrm{PI}(4,5) \mathrm{P}_{2}$ than for $\mathrm{PI}(4) \mathrm{P}$, where the $\mathrm{PI}(4,5) \mathrm{P}_{2}$ headgroup would be laying almost parallel to the membrane surface. As this cannot arise from specific electrostatic interactions in this membrane model, it is likely that this is the result of more subtle effects such as water- or alcohol-mediated hydrogen bonding. As the analysis of NMR measurements of complex systems (such as PIs) is error-prone and the "membrane matrix" used is far from being biological relevant, the authors of this study could not be definitive in their conclusions regarding $\mathrm{PI}(4,5) \mathrm{P}_{2}$ orientation. Nevertheless, they were able to replicate what had been previously observed for PI(4)P in other membrane mimetics. If these observations are replicated in more relevant conditions, they will challenge the more established "concept" of how $\mathrm{PI}(4,5) \mathrm{P}_{2}$ is structurally displayed in the membrane and how it interacts with protein partners. All-atom molecular dynamics simulations of $\mathrm{PI}(4,5) \mathrm{P}_{2}$ in lipid membranes show a well-defined average head-tail angle of roughly $100^{\circ}$, indicating that the headgroup would lie mostly flat along the membrane in agreement with the previous studies [31] (Figure 3). Poisson Boltzmann MD simulations, however, show a more conservative tilt of roughly $40^{\circ}$.

Overall, there are strong hints that, in the absence of interactions with other biochemical partners, $\mathrm{PI}(4,5) \mathrm{P}_{2}$ when inserted into a membrane has its headgroup lying tilted over the membrane, however, the extent of this tilt is still yet to be fully understood and likely depends not only on $\mathrm{PI}(4,5) \mathrm{P}_{2}$ intrinsic properties but also on the interactions with the neighboring lipid molecules. 
A

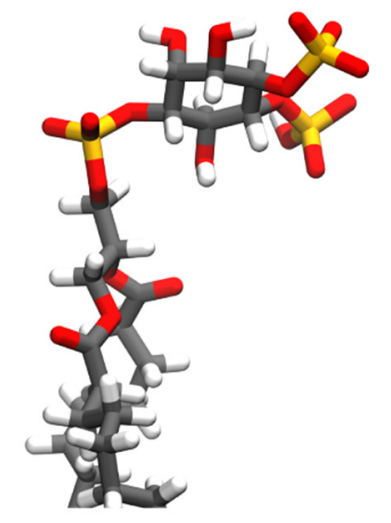

B

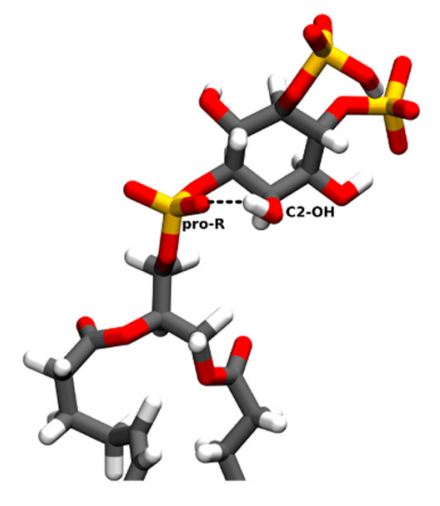

Figure 3. Examples of $\mathrm{PI}(4,5) \mathrm{P}_{2}$ headgroup tilt when inserted into a phospholipid membrane. $\mathrm{PI}(4,5) \mathrm{P}_{2}$ presents a significant headgroup tilt, when inserted into a bilayer, ranging from almost parallel to the membrane plane (A) to a more conservative $\sim 40^{\circ}$ tilt (B). Whilst the more dramatic headgroup tilt appears to be favored from interactions between its negatively charged phosphate groups and the positively charged membrane surface, the more moderate tilt surges from the establishment of intramolecular hydrogen bonds between the $\mathrm{C} 2$ hydroxyl and the pro-R-oxygen of the phosphodiester phosphate. Carbon atoms are colored in grey, hydrogen in white, oxygen in red, and phosphorus in orange. Snapshots obtained from a simulation of a bilayer consisting of 95:5 mol ratio POPC: $\mathrm{PI}(4,5) \mathrm{P}_{2}$, using the CHARMM36m forcefield run in GROMACS2019. Images were modeled using VMD.

\subsection{Headgroup Charge}

An important aspect that is closely related to the conformation of $\operatorname{PI}(4,5) \mathrm{P}_{2}$ is the charge state of each of its headgroup phosphate groups. Whilst the charge state of the headgroup linking phosphate group is well defined at physiological $\mathrm{pH}$ (pKa between 1 to 3) [32], the headgroup phosphate charges are much more volatile. The charge state of these groups has mostly been studied experimentally for PI $(4,5) \mathrm{P}_{2}$ in micelles and small unilamellar vesicles (SUVs), via 31P-NMR and the dependency of the chemical shift on the $\mathrm{pH}$. Typically, $\mathrm{PI}(4,5) \mathrm{P}_{2}$ is considered to have approximately four negative charges at cytosolic $\mathrm{pH}$. This result was inferred from the determination of the $\mathrm{pKa}$ of each headgroup phosphate in either pure or mixed vesicles of $\mathrm{PI}(4,5) \mathrm{P}_{2}$ using 31P-NMR [33]. These experiments determined a pKa value for the first protonation of roughly 6.7 and 7.7 for the phosphomonoester groups at position 4 and 5 , respectively. In terms of potential charge, this would mean that at $\mathrm{pH} 7.2$, the 5-phosphomonoester would be partially protonated at charge -1 , the 4-phosphomonoester would be fully deprotonated with charge -2 , and the phosphodiester would have charge -1 .

However, studies have since shown that the $\mathrm{PI}(4,5) \mathrm{P}_{2}$ headgroup ionization behavior (as well as for other phosphoinositides) cannot be accurately described by a Henderson-Hasselbalch mechanism [19]. In the more detailed mechanism that was proposed by the authors [19], at $\mathrm{pH}$ values close to 4-5, both phosphomonoester groups are mono-protonated as previously described. Upon increasing the $\mathrm{pH}$, one proton dissociates, whilst the remaining one is shared between the two vicinal phosphomonoester groups (Figure 2B). In terms of potential charge this means that, at $\mathrm{pH} 7.0$, the charges would be -1.58 and -1.41 for the phosphomonoester groups at positions 4 and 5, respectively. The lower charge of the 5-phosphomonoester group is attributed to the fact that it establishes a hydrogen bond interaction with the hydroxyl group in the position 6, which in turn, is also forming a long-range hydrogen bond with the phosphodiester group in the position 1 . This weakens the first hydrogen bond slightly and thus the proton binds to the 5-phosphomonoester more tightly. These results gave a much more detailed look at the charge distribution of $\mathrm{PI}(4,5) \mathrm{P}_{2}$ and at the complex network of intra- and intermolecular hydrogen bonds that lead to the dissipation of the headgroup charge and are, very likely, part of the reason for why repulsion between phosphoinositides is much weaker than expected. 
A fact that is often overlooked is how the interaction of $\mathrm{PI}(4,5) \mathrm{P}_{2}$ with neighboring molecules influences its charge distribution. In vivo, $\mathrm{PI}(4,5) \mathrm{P}_{2}$ is constantly in interaction not only with its neighboring lipids but also with proteins and cationic ions. The complex network of interactions formed by $\mathrm{PI}(4,5) \mathrm{P}_{2}$ with these partners leads to a greater distribution of its charge, effectively altering its headgroup charge. A study has shown that, in the absence of divalent cations, lipids with hydrogen bond donor capabilities could influence $\mathrm{PI}(4,5) \mathrm{P}_{2}$ headgroup charge [34]. Phosphatidylethanolamine (PE) was shown to influence the first step of deprotonation of the $\mathrm{PI}(4,5) \mathrm{P}_{2}$ headgroup, most likely by interacting preferably with the 5-phosphate. In the presence of PI, the first step of deprotonation was not affected, however, a lower degree of ionization was observed for both phosphomonoester groups for the removal of the last shared proton. Curiously, phosphatidylserine (PS) was not shown to affect $\mathrm{PI}(4,5) \mathrm{P}_{2}$ headgroup ionization significantly. This study clearly showcases how the $\mathrm{PI}(4,5) \mathrm{P}_{2}$ local environment can affect $\mathrm{PI}(4,5) \mathrm{P}_{2}$ headgroup charge, a crucial feature responsible for a lot of its biological function.

\subsection{Acyl-Chain Composition}

The acyl-chain composition of lipids often plays an important functional role. These roles can be defined by specific interactions with proteins or by simply changing the overall biophysical properties of the surrounding membrane. In general, fatty acid profiles vary between phospholipid classes, tissues, and species and can also vary over time with dietary habits, stimuli, or disease. Like many other lipids, $\mathrm{PI}(4,5) \mathrm{P}_{2}$ is also subject to these effects. In mammals, the phosphorylated myo-inositol headgroup is typically bound to a DAG moiety, which consists of two fatty acid chains bonded to a glycerol molecule via ester bonds at positions $s n 1$ and $s n 2$. The major fatty acid profile observed for $\mathrm{PI}(4,5) \mathrm{P}_{2}$ in mammals consists of 1-stearoyl-2-arachidonyl (18:0/20:4) [23]. Curiously, inositol-phosphate headgroups coupled to ceramide have also been identified in fungi, plants, and protozoa [35], however, we will focus only on the mammal relevant DAG-bound species in this review.

The 18:0/20:4 acyl-chain profile consists of up to $70 \%$ of the total $\mathrm{PI}(4,5) \mathrm{P}_{2}$ lipid pool in some cell lines, especially in brain tissue. This enrichment is likely the combined outcome of substrate specificity for 1-stearoyl-2-arachidonyl-glycerol in several enzymes in the phosphatidylinositol cycle and the remodeling of phosphoinositide acyl-chains via the Land's cycle [36]. A more detailed look at how the cell might maintain this enrichment can be seen in this review by D'Souza et al. (2014) [36]. However, $\mathrm{PI}(4,5) \mathrm{P}_{2}$ still has a broad distribution profile ranging from highly unsaturated chains to fully saturated ones [37]. These less abundant species become more prevalent in response to certain stimuli [38], stress [37,38], aging [37], or in cancer [39]. In these cases, fully saturated and mono-unsaturated compositions increase significantly in concentration, in some cases even surpassing the canonical 1-stearoyl-2-arachidonyl (18:0/20:4) composition [38].

However, why do cells spend so many resources in maintaining this particular acyl-chain composition? And why does the acyl-chain profile shift, sometimes dramatically, in specific conditions? The biological functions behind the enrichment in 18:0/20:4 are still not very clear. The enrichment in this configuration seems to be particularly prevalent in brain cells, where $\mathrm{PI}(4,5) \mathrm{P}_{2}$ has been associated with several stages of both endocytosis and exocytosis and has been considered an important mediator of synaptic vesicle trafficking [40]. It has been shown that arachidonate, and other polyunsaturated fatty acids such as docosahexaenoate (22:6), at the sn2 position, facilitate membrane shaping and fission activities. Additionally, asymmetric sn1-saturated-sn2-polyunsaturated phospholipids have been shown to provide efficient membrane vesiculation whilst maintaining lower membrane permeability [41]. These properties might provide significant mechanical benefits in these particular tissues. Of course, arachidonic acid in particular has biological activity of its own in addition to serving as the precursor for the synthesis of eicosanoids, such as prostaglandins and leukotrienes [42]. Overall, this particular theme has been given little attention thus far, however, it could be the key for some of $\mathrm{PI}(4,5) \mathrm{P}_{2}$ multifunctionality. 


\section{Lateral Organization of $\mathrm{PI}(4,5) \mathrm{P}_{2}$}

Having looked at the core structural properties of $\mathrm{PI}(4,5) \mathrm{P}_{2}$ we now turn to its organization in the plasma membrane. As $\mathrm{PI}(4,5) \mathrm{P}_{2}$ is engaged in a multitude of cellular functions occurring in parallel, its levels must be tightly regulated to avoid significant fluctuations of its total plasma membrane concentration. This implies that the simultaneous regulation of these cellular functions by $\mathrm{PI}(4,5) \mathrm{P}_{2}$ must occur through the presence of multiple localized pools of this phospholipid in the plasma membrane [43]. PI $(4,5) \mathrm{P}_{2}$ lateral organization in cells has been studied through a variety of techniques from fluorescence correlation spectroscopy (FCS) and fluorescence recovery after photobleaching (FRAP) to atomic force microscopy (AFM). In FCS experiments carried out in Rat1 fibroblasts and HEK cells, researchers microinjected micelles of fluorescent labelled-PI $(4,5) \mathrm{P}_{2}$ into cells and showed that the diffusion coefficient of $\mathrm{PI}(4,5) \mathrm{P}_{2}$ in these cells is significantly lower than expected for free phospholipids. The simplest interpretation of this result is that approximately two-thirds of $\mathrm{PI}(4,5) \mathrm{P}_{2}$ in the inner leaflet of the plasma membrane is somehow sequestered [44]. Studies in PC12 cells have also shown, using Stimulated emission depletion (STED) microscopy [45] and Stochastic optical reconstruction microscopy (STORM) imaging techniques [46], that $\mathrm{PI}(4,5) \mathrm{P}_{2}$ is highly enriched in nanometer-sized membrane domains, specific to this cellular model.

In fact, while the presence of segregated $\mathrm{PI}(4,5) \mathrm{P}_{2}$ pools can be partly explained by localized $\mathrm{PI}(4,5) \mathrm{P}_{2}$ synthesis and degradation through several kinases and phosphatases [47], it is also evident that membrane diffusion rates, in the absence of significant obstacles for diffusion, will always be higher than concentration changes due to enzymatic activity causing $\mathrm{PI}(4,5) \mathrm{P}_{2}$ to diffuse away faster than it can be produced. This means that it is unlikely that local synthesis can result in significant changes in the submicroscopic organization of $\mathrm{PI}(4,5) \mathrm{P}_{2}$ in the membrane [43]. $\mathrm{PI}(4,5) \mathrm{P}_{2}$ interactions with other cellular binding partners could alternatively explain the observed lateral organization of this phosphoinositide. Interactions with proteins, divalent cations, cholesterol, and the cytoskeleton are the ones most likely to have such an impact. In this review, we will give particular attention to the often neglected effect of divalent cations on the lateral organization of $\mathrm{PI}(4,5) \mathrm{P}_{2}$.

\subsection{Sequestration by Proteins}

One way to explain $\mathrm{PI}(4,5) \mathrm{P}_{2}$ lateral organization in the plasma membrane of cells is that proteins can act as reversible buffers, binding much of the $\mathrm{PI}(4,5) \mathrm{P}_{2}$ present and then releasing it locally in response to specific signals [48]. Theoretical simulations predict that such sequestration can be achieved not only through specific interactions with $\mathrm{PI}(4,5) \mathrm{P}_{2}$ but also through nonspecific electrostatic interactions. In fact, polybasic proteins are able to sequester a lipid with a valence of $\sim 4$ (such as $\left.\mathrm{PI}(4,5) \mathrm{P}_{2}\right) 1000$-fold more effectively than a lipid with a valence of $\sim 1$ (such as PS) [49,50]. Due to its highly negatively charged headgroup, $\mathrm{PI}(4,5) \mathrm{P}_{2}$ was confirmed to interact strongly with polybasic stretches of amino acid residues [43,51]. Through these polybasic stretches, several proteins were found to laterally sequester $\mathrm{PI}(4,5) \mathrm{P}_{2}$ molecules in a reversible manner [52,53]. For an efficient buffering of $\mathrm{PI}(4,5) \mathrm{P}_{2}$ levels, these proteins would have to be present at a concentration comparable to $\mathrm{PI}(4,5) \mathrm{P}_{2}$, localize to the plasma membrane and be able to bind $\mathrm{PI}(4,5) \mathrm{P}_{2}$ with high affinity while being able to release it in response to stimuli. Proteins such as myristoylated alanine-rich C-kinase substrate (MARCKS) [50,53,54], Growth Associated Protein 43 (GAP43) [48,55], CAP23 [48], among many others, have been shown to be able to sequester $\mathrm{PI}(4,5) \mathrm{P}_{2}$ in such a manner. In the case described above of $\mathrm{PI}(4,5) \mathrm{P}_{2}$ domains detected in PC12 cells, these were found to be associated with the sequestration of $\mathrm{PI}(4,5) \mathrm{P}_{2}$ to clusters of the SNARE protein syntaxin-1 [45,56,57]. This sequestration by syntaxin- 1 is critical for the regulation of SNARE-dependent membrane fusion [58,59].

Employing fluorescence and electron paramagnetic resonance spectroscopic tools, McLaughlin, Cafiso, and co-workers [50,52] showed that a 24 aa peptide corresponding to the effector domain of MARCKS was able to efficiently sequester an average of $3 \mathrm{PI}(4,5) \mathrm{P}_{2}$ molecules through non-specific electrostatic interactions. Importantly, this sequestration occurred even in the presence of physiological concentrations of the monovalent acidic phospholipid PS, confirming theoretical predictions. MARCKS 
sequestration of $\mathrm{PI}(4,5) \mathrm{P}_{2}$ has been shown to be important in the $\mathrm{PI}(4,5) \mathrm{P}_{2}$ mediated activation of TRPC-family $\mathrm{Ca}^{2+}$ channels [60], in the endocytosis of the amyloid precursor protein (APP) [61], and in the synaptic clustering of $\mathrm{PI}(4,5) \mathrm{P}_{2}[62]$.

\section{2. $P I(4,5) P_{2}$ Interactions with Divalent Cations}

Several studies have shown that PIs and $\mathrm{PI}(4,5) \mathrm{P}_{2}$, in particular, are able to establish strong electrostatic interactions between their negatively charged headgroups and divalent cations. In the cellular $\mathrm{PI}(4,5) \mathrm{P}_{2}$ context, calcium and magnesium stand out. Calcium is a common player in signal transduction and a second messenger in cells. Its levels are strictly controlled and maintained at low levels in the cytosol, with normal intracellular levels at around $100 \mathrm{nM}(20,000$ fold lower than extracellular levels) [63]. Upon stimulation, however, several signal transduction pathways can lead to transient increases of intracellular calcium concentration up to around $1 \mu \mathrm{M}$, with local concentrations in the vicinity of open calcium channels reaching hundreds of $\mu \mathrm{M}$, before being regulated back to normal levels [64]. In fact, $\mathrm{PI}(4,5) \mathrm{P}_{2}$ has been reported to be associated with a variety of $\mathrm{Ca}^{2+}$ channels and a great number of these require $\mathrm{PI}(4,5) \mathrm{P}_{2}$ for proper function [3]. Magnesium, on the other hand, is a less studied modulator of cell function. Magnesium levels are well buffered in a narrow millimolar range between $0.25 \mathrm{mM}$ and $1 \mathrm{mM}[65,66]$ and are thus kept at a much higher concentration than those of calcium. Both divalent cations have been shown to bind strongly to $\mathrm{PI}(4,5) \mathrm{P}_{2}$ and influence its lateral organization dramatically as discussed below.

Through hybrid Quantum mechanics/molecular mechanics (QM/MM) experiments we can get an insight on the molecular basis for cation binding to $\mathrm{PI}(4,5) \mathrm{P}_{2}$ [31]. From a molecular point of view, when binding to a single $\mathrm{PI}(4,5) \mathrm{P}_{2}$ lipid, both calcium and magnesium bind to $\mathrm{PI}(4,5) \mathrm{P}_{2}$ either in between the phosphomonoester groups (Figure 4B) or solely near the 4-phophomonoester (Figure 4A). However, simultaneous binding between the two phosphomonoester groups is approximately $10 \mathrm{kcal} / \mathrm{mol}$ more unfavorable [31]. Divalent cation binding to the phosphodiester group has also been observed [67].

When analyzing the free energy associated with the removal of each divalent cation from its binding position, significantly more energy is required to remove calcium into the bulk water than it is for magnesium. The difference in free energy could come from the fact that, in contrast to calcium, magnesium appears to retain its first hydration shell in its equilibrium binding position. This causes its equilibrium binding position to be further away from the headgroup and leads to the formation of fewer hydrogen bonds, on average, between the headgroup and the surrounding water molecules. Interestingly, it was also shown that upon binding to calcium, the remaining $\mathrm{PI}(4,5) \mathrm{P}_{2}$ headgroup proton at physiological $\mathrm{pH}$ could be favorably displaced and that the effective size of the $\mathrm{PI}(4,5) \mathrm{P}_{2}$ headgroup would significantly decrease [31]. In the presence of magnesium, the dissociation of the remaining proton was not favorable, however, the decrease in effective headgroup surface area was also observed albeit to a lesser extent. All of these cation-induced changes can and will affect $\mathrm{PI}(4,5) \mathrm{P}_{2}$ dynamics, thus influencing local membrane dynamics as well as its interactions with protein binding partners.

Apart from simply binding to $\mathrm{PI}(4,5) \mathrm{P}_{2}$, both divalent cations also have the ability to crosslink $\mathrm{PI}(4,5) \mathrm{P}_{2}$ lipids. This induces the formation of very stable cation-induced $\mathrm{PI}(4,5) \mathrm{P}_{2}$ nanodomains. It has been shown through different experimental techniques that divalent cations, and especially calcium, are able to induce the formation of $\mathrm{PI}(4,5) \mathrm{P}_{2}$ nanodomains, even at physiological concentrations of cation and lipid. In lipid monolayers, these clusters can be detected through AFM [68,69] (Figure 5). Through the use of fluorescent analogs of $\mathrm{PI}(4,5) \mathrm{P}_{2}$, calcium-induced clusters were shown to occur in model membranes at physiologically relevant concentrations of both calcium and $\mathrm{PI}(4,5) \mathrm{P}_{2}[70]$. Other phosphoinositides have also shown some propensity to form cation-induced clusters. $\mathrm{PI}(3,5) \mathrm{P}_{2}$ has been found to form nanodomains by itself in the presence of physiological concentrations of calcium cations, however, in the presence of magnesium clustering was negligible [71]. On top of that, the clusters formed by $\mathrm{PI}(3,5) \mathrm{P}_{2}$ were much smaller and likely less stable than those formed by 
$\mathrm{PI}(4,5) \mathrm{P}_{2}$ [71]. On the other hand, when the monophosphorylated $\mathrm{PI}(4) \mathrm{P}$ was tested in the same type of experiments, no calcium-induced clusters were observed [71].

A

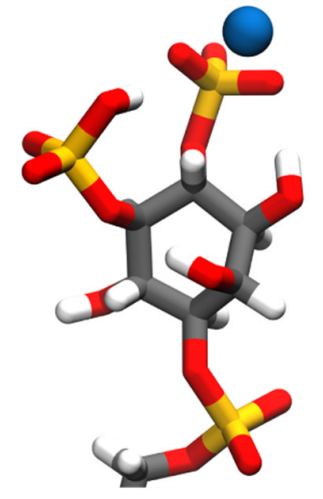

B

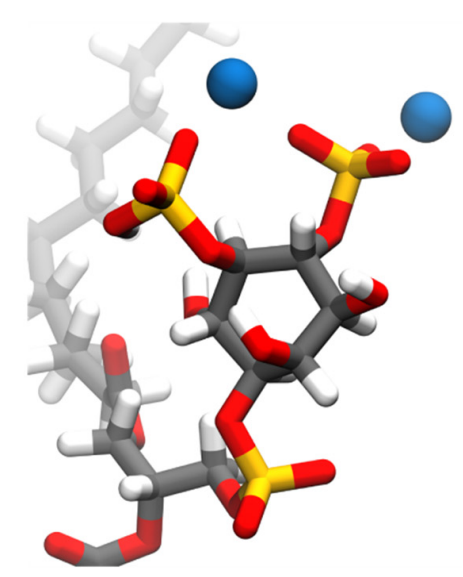

Figure 4. Snapshots of calcium ions interacting with the $\mathrm{PI}(4,5) \mathrm{P}_{2}$ headgroup phosphates. Calcium can bind to $\mathrm{PI}(4,5) \mathrm{P}_{2}$ either solely near the 4-phophomonoester $(\mathbf{A})$ or in between the phosphomonoester groups (B). However, simultaneous binding between the two phosphomonoester groups is approximately $10 \mathrm{kcal} / \mathrm{mol}$ more unfavorable [31]. Carbon atoms are colored in grey, hydrogen in white, oxygen in red, phosphorus in orange, and calcium in blue. Snapshots obtained from a simulation of a bilayer consisting of 95:5 mol ratio POPC: $\mathrm{PI}(4,5) \mathrm{P}_{2}$ in the presence of calcium in a 5:1 calcium to $\mathrm{PI}(4,5) \mathrm{P}_{2}$ ratio, using the CHARMM36m forcefield run in GROMACS2019. Images were modeled using VMD.
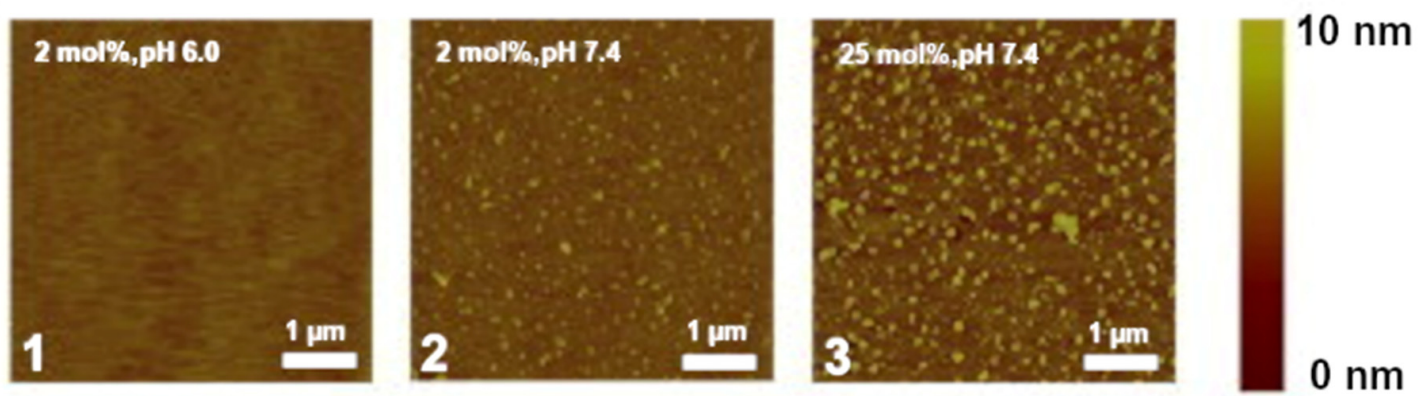

Figure 5. Snapshots of experiments on mixed lipid monolayers, containing different mol $\%$ of 1-stearoyl-2-oleoyl-sn-glycero-3-phosphocholine (SOPC) and PI(4,5)P2, while exposed to calcium. Reprinted from Biophysical Journal, 101, Ellenbroek, W.G.; Wang, Y.H.; Christian, D.A.; Discher, D.E.; Janmey, P.A.; Liu, A.J. Divalent cation-dependent formation of electrostatic PIP2 clusters in lipid monolayers. 2178-2184, Copyright (2011), with permission from Elsevier [69].

From a molecular point of view, a single divalent cation can likely crosslink up to $2 \mathrm{PI}(4,5) \mathrm{P}_{2}$ lipids by simultaneously binding each lipid phosphodiester and/or headgroup phosphomonoester groups via strong electrostatic interactions [72]. A single $\mathrm{PI}(4,5) \mathrm{P}_{2}$ lipid, however, can simultaneously bind up to 3 divalent cations, and thus be complexed with 3 other $\mathrm{PI}(4,5) \mathrm{P}_{2}$ lipids (Figure 6). This net of $\mathrm{PI}(4,5) \mathrm{P}_{2}$ - cation interactions can thus induce the formation of a grid of tightly crosslinked lipids. Whilst the main driving force behind the clustering appears to be cation crosslinking, the formation of a complex network of intermolecular hydrogen bonds, between the headgroup hydroxyl and phosphomonoester groups, very likely plays a role in thermodynamically favoring clustering. Due to the electrostatic nature of the cation interactions, the propensity to crosslink PI $(4,5) \mathrm{P}_{2}$ lipids appears to be highly correlated with the affinity towards the divalent cation. Thus, $\mathrm{Ca}^{2+}$ shows a much greater clustering propensity than magnesium. In fact, $\mathrm{Ca}^{2+}$ induced clusters have been shown to 
be significantly larger than those induced by magnesium at the same experimental conditions [68]. However, although magnesium has a much weaker affinity for $\mathrm{PI}(4,5) \mathrm{P}_{2}$ when compared to calcium, its steady-state levels are several orders of magnitude higher than those of calcium, and at these $\mathrm{mM}$ concentrations, it is also able to induce comparable $\mathrm{PI}(4,5) \mathrm{P}_{2}$ clustering [71].

As the formation of these clusters is driven mainly by the crosslinking of the phosphate groups, the nanodomains formed are composed of almost only $\mathrm{PI}(4,5) \mathrm{P}_{2}$. Studies have shown that other phosphorylated PI species can co-cluster with $\mathrm{PI}(4,5) \mathrm{P}_{2}$, albeit to a lesser degree, but that the parent lipid phosphatidylinositol cannot [73]. Incorporation into clusters also seems to be independent from acyl-chain composition [73], however, it is very likely that different acyl-chain compositions induce the formation of nanodomains with different biophysical properties.

A

B
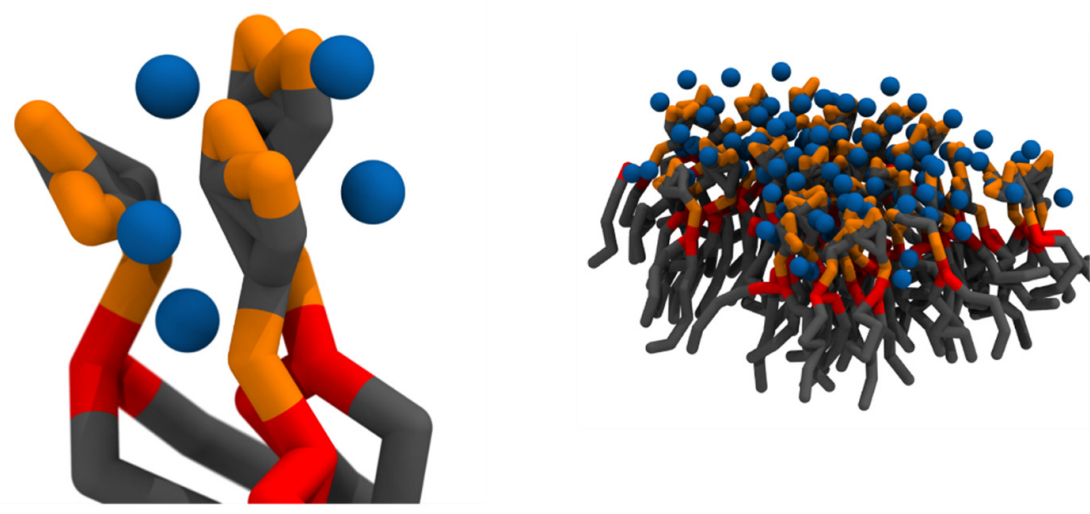

Figure 6. Crosslinking of $\mathrm{PI}(4,5) \mathrm{P}_{2}$ lipids induces the formation of $\mathrm{PI}(4,5) \mathrm{P}_{2}$ nanodomains. As a single divalent cation can bind up to $2 \mathrm{PI}(4,5) \mathrm{P}_{2}$ lipids and each lipid can potentially bind 3 divalent cations, a network of electrostatic interactions can crosslink $\mathrm{PI}(4,5) \mathrm{P}_{2}$ lipids together $(\mathrm{A})$. As the number of clustered lipids increases, $\mathrm{PI}(4,5) \mathrm{P}_{2}$ nanodomains are formed $(\mathbf{B})$. Coarse grain beads representing the inositol headgroup and acyl-chains are colored in grey, the glycerol component in red, the phosphate groups in orange, and calcium in blue. Snapshots obtained from a simulation of a bilayer consisting of 95:5 mol ratio POPC: $\mathrm{PI}(4,5) \mathrm{P}_{2}$ in the presence of calcium in a 5:1 calcium to $\mathrm{PI}(4,5) \mathrm{P}_{2}$ ratio, using the martini 2.2 coarse-grained forcefield run in GROMACS2019. Images were modeled using VMD.

These cation-induced $\mathrm{PI}(4,5) \mathrm{P}_{2}$ nanodomains are much more than simply the sum of their elements. While calcium is known to directly regulate the interaction of different protein domains to $\mathrm{PI}(4,5) \mathrm{P}_{2}[74]$, the structure and dynamics of the phospholipid within the divalent cation-induced cluster present markedly distinct biophysical characteristics than the monodisperse lipid. As mentioned previously, binding of divalent cations, and in particular calcium, can alter $\mathrm{PI}(4,5) \mathrm{P}_{2}$ headgroup exposure leading to a decrease in solvent-accessible area [31]. Additionally, as divalent cations accumulate, significant screening of the headgroup charges occurs, essentially shielding the large negatively charged headgroup from potential binding partners [75]. As $\mathrm{PI}(4,5) \mathrm{P}_{2}$ lipids are forced to accumulate in an enclosed area, further reorganization of the headgroups occurs, promoted by the molecular interactions of the divalent cations with the 3 phosphate groups [76], effectively altering the headgroup conformation. This local accumulation likely influences $\mathrm{PI}(4,5) \mathrm{P}_{2}$ acyl-chain dynamics and, therefore, local membrane order. Studies have shown that $\mathrm{PI}(4,5) \mathrm{P}_{2}$ nanodomains have significantly reduced lateral dynamics [70] and that $\mathrm{PI}(4,5) \mathrm{P}_{2}$, which as a single lipid has a strong preference for disordered domains, displays significantly less affinity for disordered domains upon clustering [71]. All of these altered biophysical properties can, and most likely will, influence downstream $\mathrm{PI}(4,5) \mathrm{P}_{2}$ signaling by modulating its interactions with protein and lipid partners. 
Altogether, these findings show that divalent cation-mediated clustering can lead to the formation of specific sites in the membrane highly enriched in $\mathrm{PI}(4,5) \mathrm{P}_{2}$ while depleting the rest of the membrane [70]. $\mathrm{PI}(4,5) \mathrm{P}_{2}$ is likely constitutively clustered in the membrane, crosslinked by $\mathrm{Mg}^{2+}$ ions alongside other minor phosphoinositide lipids. In the vicinity of active calcium channels, where calcium concentrations increase significantly upon opening of a channel, both ions will simultaneously contribute to the formation of the nanodomains, to form larger and more stable $\mathrm{PI}(4,5) \mathrm{P}_{2}$ nanodomains. These cation-induced nanodomains can influence not only $\mathrm{PI}(4,5) \mathrm{P}_{2}$ lateral organization and biophysical properties but also the way proteins interact with $\mathrm{PI}(4,5) \mathrm{P}_{2}$, by modulating their localization in the plasma membrane, their target recognition and binding affinity to $\mathrm{PI}(4,5) \mathrm{P}_{2}$, and even further downstream interactions with other proteins. Therefore, beyond the impact of calcium on $\mathrm{PI}(4,5) \mathrm{P}_{2}$ levels in the membrane through activation of phospholipase activity, the direct interaction of divalent cations with $\mathrm{PI}(4,5) \mathrm{P}_{2}$ is expected to play a crucial role in the regulation of the biological activity of this phospholipid.

\subsection{Effect of Cholesterol on PI(4,5)P2 Properties and Distribution}

Cholesterol is a crucial membrane component, implicated in a myriad of membrane processes. However, its most noted role is in the regulation of plasma membrane biophysical properties as a "fluidity buffer". Whilst its effects can vary with different cholesterol contents, cholesterol, in general, decreases membrane fluidity by increasing lipid packing even leading to the cholesterol-dependent formation of coexisting liquid phases [77]. Like all the other phospholipids in the plasma membrane, $\mathrm{PI}(4,5) \mathrm{P}_{2}$ is also subject to these cholesterol-dependent effects.

Unsurprisingly, given its large negatively charged headgroup and highly unsaturated acyl chain, $\mathrm{PI}(4,5) \mathrm{P}_{2}$ was shown to preferentially partition into the less ordered cholesterol-poor phases of biphasic monolayers containing PI(4,5) $\mathrm{P}_{2}: \mathrm{SOPC}$ :Chol [78]. However, after the addition of calcium, the subsequent cation-induced $\mathrm{PI}(4,5) \mathrm{P}_{2}$ nanodomains were shown to have increased the miscibility of the coexisting domains in the cholesterol-containing monolayers [78]. Related results have been observed, in a study with fluorescent derivatives of $\mathrm{PI}(4,5) \mathrm{P}_{2}$ incorporated in ternary mixtures of POPC:SM:Chol. In this study, monodisperse $\mathrm{PI}(4,5) \mathrm{P}_{2}$ presented low miscibility in more ordered lipid phases, yet, after cation-induced clustering, the preference for disordered domains decreased by more than two-fold [78]. Importantly, the lipid composition of this ternary mixture was shown to have a marked influence both on the extent of $\mathrm{PI}(4,5) \mathrm{P}_{2}$ calcium-induced clustering and on the size of clusters formed (Figure 7) [78]. Since the dimensions of $\mathrm{PI}(4,5) \mathrm{P}_{2}$ clusters were heavily dependent on temperature, it was concluded that the major factor regulating $\mathrm{PI}(4,5) \mathrm{P}_{2}$ clustering was membrane order and not the presence of a specific molecular partner in the membrane. This suggests that the insertion of $\mathrm{PI}(4,5) \mathrm{P}_{2}$ in more ordered domains is stabilized by the formation of cation-induced nanodomains. In a cellular context, the effect of cholesterol on $\mathrm{PI}(4,5) \mathrm{P}_{2}$ appears to be heavily dependent on cell type. In fibroblasts [79] and cultured pancreatic $\beta$-cells [80], cholesterol depletion leads to decreased levels of free $\mathrm{PI}(4,5) \mathrm{P}_{2}$, whilst in HEK293 [81] cholesterol enrichment was shown to promote $\mathrm{PI}(4,5) \mathrm{P}_{2}$ depletion.

Altogether, the findings we have previously discussed appear to be in agreement with theories that associate $\mathrm{PI}(4,5) \mathrm{P}_{2}$ with the controversial cholesterol-rich microdomains, such as "lipid rafts" and caveolae, which are said to be involved in regulating a variety of membrane functions. $\mathrm{PI}(4,5) \mathrm{P}_{2}$ has been found to be enriched in detergent-resistant membranes [82]. Moreover, while detergent extraction has been put into question on whether it induces an artefactual enrichment in $\mathrm{PI}(4,5) \mathrm{P}_{2}[83]$, studies have shown PI $(4,5) \mathrm{P}_{2}$ to colocalize with more ordered membrane domains [84-87] and to be sensitive to membrane curvature $[87,88]$, both associated with these types of structures. Interestingly, in a study where a PI $(4,5) \mathrm{P}_{2}$-specific phosphatase was targeted to either the "raft" or the "nonraft" membrane fractions of $\mathrm{T}$ cells, the authors were able to show clear evidence of compartmentalization of $\mathrm{PI}(4,5) \mathrm{P}_{2}$-dependent signaling in each of the fractions. When depleting the "nonraft" fraction of $\mathrm{PI}(4,5) \mathrm{P}_{2}, \mathrm{~T}$ cells showed an increase in cell filopodia and cell spreading, whilst in contrast, when depleting the "raft" fraction of $\mathrm{PI}(4,5) \mathrm{P}_{2}$, T cells showed smooth membranes free of ruffling 
and filopodia among other effects. Findings also appear to suggest that roughly half of the $\mathrm{PI}(4,5) \mathrm{P}_{2}$ content is synthesized preferentially in these cholesterol-enriched domains [82]. Nonetheless, this is still an area of great controversy amongst researchers, and there is a lot yet to uncover before significant conclusions can be drawn on the importance of these microdomains for $\mathrm{PI}(4,5) \mathrm{P}_{2}$ lateral organization.

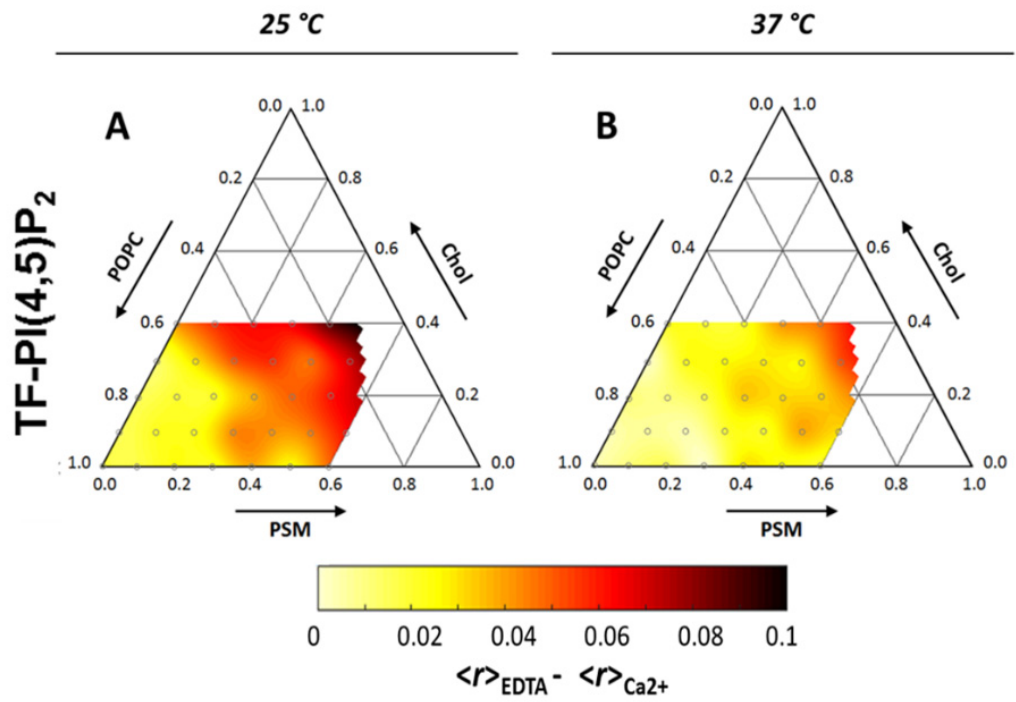

Figure 7. Ternary diagram for the POPC:PSM:Chol lipid mixture at $25^{\circ} \mathrm{C}(\mathbf{A})$ and $37^{\circ} \mathrm{C}(\mathbf{B})$. Color-code depicts decrease in measured fluorescence anisotropies of a $\mathrm{PI}(4,5) \mathrm{P}_{2}$ fluorescent analog $\left(\mathrm{TF}-\mathrm{PI}(4,5) \mathrm{P}_{2}\right)$ upon inclusion of $100 \mu \mathrm{M} \mathrm{Ca}^{2+}$. Since the decrease reflects homo-FRET between analogs incorporated within the same clusters, darker areas correspond to more efficient $\mathrm{PI}(4,5) \mathrm{P}_{2}$ clustering. Adapted with permission from Sarmento, M.J.; Coutinho, A.; Fedorov, A.; Prieto, M.; Fernandes, F. Membrane order is a key regulator of divalent cation-induced clustering of $\mathrm{PI}(3,5) \mathrm{P}_{2}$ and $\mathrm{PI}(4,5) \mathrm{P}_{2}$. Langmuir 2017, 33, 12463-12477 [78]. Copyright (2017) American Chemical Society.

\subsection{Effect of the Cytoskeleton and Curvature on PI $(4,5)$ P2 Lateral Organization}

$\mathrm{PI}(4,5) \mathrm{P}_{2}$ has been shown to be a major player in cytoskeleton dynamics, by interacting and regulating the activity of numerous enzymes and cytoskeletal proteins [89,90]. However, the cytoskeleton can also regulate $\mathrm{PI}(4,5) \mathrm{P}_{2}$, and in particular its lateral organization, via corralling by the cortical actin network. Cortical actin networks have been shown to be able to induce spatio-temporal confinement of phospholipids in the plasma membrane of living cells [91]. PI $(4,5) \mathrm{P}_{2}$ should be no exception to this effect and, in fact, due to its close proximity with a variety of actin-binding proteins [90], one can suspect it could be even more susceptible to these effects. Studies have shown that the cytoskeleton is responsible for some of the low mobility of $\mathrm{PI}(4,5) \mathrm{P}_{2}$ in atrial myocytes [92].

Curvature can also greatly influence $\mathrm{PI}(4,5) \mathrm{P}_{2}$ lateral organization. $\mathrm{PI}(4,5) \mathrm{P}_{2}$ has been found to undergo a transient increase at the phagocytic cup during the initiation of phagocytosis [93,94]. More recently, it was found that the curvature induced by the engagement of non-biological solid particles with the plasma membrane was enough to increase $\mathrm{PI}(4,5) \mathrm{P}_{2}$ concentrations at the site of contact. Additionally, as we previously discussed, $\mathrm{PI}(4,5) \mathrm{P}_{2}$ has been associated with several stages of endocytosis and exocytosis, where curvature effects are paramount [40]. As a monodisperse lipid, $\mathrm{PI}(4,5) \mathrm{P}_{2}$ has an inverted cone-shaped structure [95] due to its very large inositol headgroup. As such, it is associated with positive membrane curvature. After interacting with divalent cations, however, $\mathrm{PI}(4,5) \mathrm{P}_{2}$ presents a cone-shaped structure [95], likely due to the decrease in headgroup area as well as the aggregation of the headgroups after complexation with the cations. In this case, it would be associated with negative membrane curvature. Whether local curvature at the plasma membrane plays a major role in dictating $\mathrm{PI}(4,5) \mathrm{P}_{2}$ lateral organization or $\mathrm{PI}(4,5) \mathrm{P}_{2}$ lateral organization contributes 
to local curvature is not entirely clear. In a cellular context, it is likely dependent on the process in question and the overall result of both effects.

\section{Concluding Remarks}

Despite having been discussed separately in this review, all the complex biophysical properties we discussed previously are tightly interlinked processes. Furthermore, it is the combined effect of these properties that allows $\mathrm{PI}(4,5) \mathrm{P}_{2}$ to be a major regulator of membrane dynamics despite being present at very low overall concentrations. While a lot of research has been conducted on these effects, many are still to be fully characterized, especially those associated with cation-induced nanodomains, such as the lipid conformation in these structures, the extent of charge dissipation, and the effect of these nanodomains on the local bilayer properties. A good molecular understanding of these effects is fundamental in order to better understand how $\mathrm{PI}(4,5) \mathrm{P}_{2}$ carries out its role as a major plasma membrane regulator.

Over the last decades, extensive research efforts have uncovered a multitude of different cellular roles of $\mathrm{PI}(4,5) \mathrm{P}_{2}$. However, the current view on the majority of the mechanisms associated with these functions neglects the almost certain presence of a highly significant, if not dominant, pool of this phospholipid that is not monodispersed. Special consideration should be given to the fact that in the plasma membrane, $\mathrm{PI}(4,5) \mathrm{P}_{2}$ must be either protein-bound or constitutively complexed with divalent cations within small clusters. $\mathrm{PI}(4,5) \mathrm{P}_{2}$ within these structures is bound to have significantly different properties from the monodisperse lipid. These properties can influence $\mathrm{PI}(4,5) \mathrm{P}_{2}$ interactions with its binding partners (such as proteins) as well as downstream protein-protein interactions. It is conceivable that many of $\mathrm{PI}(4,5) \mathrm{P}_{2}$ cellular functions are also regulated by the extent of this effect.

Funding: L.B.A. thanks to The Medical Biochemistry and Biophysics Doctoral Programme (M2B-PhD) and the Portuguese Science and Technology Foundation (FCT) for a PhD fellowship (PD/BD/137492/2018). Authors acknowledge funding by FCT project reference IF/00386/2015/CP1272/CT0010 and PTDC/BTM-SAL/31057/2017.

Conflicts of Interest: The authors declare no conflict of interest. The funders had no role in the writing of the manuscript.

\section{References}

1. Viaud, J.; Mansour, R.; Antkowiak, A.; Mujalli, A.; Valet, C.; Chicanne, G.; Xuereb, J.M.; Terrisse, A.D.; Séverin, S.; Gratacap, M.P.; et al. Phosphoinositides: Important lipids in the coordination of cell dynamics. Biochimie 2016, 125, 250-258. [CrossRef]

2. Berridge, M.J. Inositol Trisphosphate and Diacylglycerol: Two Interacting Second Messengers. Annu. Rev. Biochem. 1987, 56, 159-193. [CrossRef] [PubMed]

3. Ballac, T. Phosphoinositides: Tiny lipids with giant impact on cell regulation. Physiol. Rev. 2013, 93, 1019-1137. [CrossRef] [PubMed]

4. Tsujita, K.; Itoh, T. Phosphoinositides in the regulation of actin cortex and cell migration. Biochim. Biophys. Acta Mol. Cell Biol. Lipids 2015, 1851, 824-831. [CrossRef] [PubMed]

5. Hilgemann, D.W.; Feng, S.; Nasuhoglu, C. The complex and intriguing lives of PIP2 with ion channels and transporters. Sci. STKE 2001, 2001, re19. [CrossRef]

6. Hille, B.; Dickson, E.J; Kruse, M.; Vivas, O.; Suh, B.C. Phosphoinositides regulate ion channels. Biochim. Biophys. Acta 2015, 1851, 844-856. [CrossRef]

7. Höning, S.; Ricotta, D.; Krauss, M.; Späte, K.; Spolaore, B.; Motley, A.; Robinson, M.; Robinson, C.; Haucke, V.; Owen, D.J. Phosphatidylinositol-(4,5)-Bisphosphate Regulates Sorting Signal Recognition by the Clathrin-Associated Adaptor Complex AP2. Mol. Cell 2005, 18, 519-531. [CrossRef]

8. Wenk, M.R.; De Camilli, P. Protein-lipid interactions and phosphoinositide metabolism in membrane traffic: Insights from vesicle recycling in nerve terminals. Proc. Natl. Acad. Sci. USA 2004, 101, 8262-8269. [CrossRef]

9. Simonsen, A.; Wurmser, A.E.; Emr, S.D.; Stenmark, H. The role of phosphoinositides in membrane transport. Curr. Opin. Cell Biol. 2001, 13, 485-492. [CrossRef]

10. Posor, Y.; Eichhorn-Grünig, M.; Haucke, V. Phosphoinositides in endocytosis. Biochim. Biophys. Acta 2015, 1851, 794-804. [CrossRef] 
11. Levin, R.; Grinstein, S.; Schlam, D. Phosphoinositides in phagocytosis and macropinocytosis. Biochim. Biophys. Acta Mol. Cell Biol. Lipids 2015, 1851, 805-823. [CrossRef] [PubMed]

12. Holz, R.W.; Hlubek, M.D.; Sorensen, S.D.; Fisher, S.K.; Balla, T.; Ozaki, S.; Prestwich, G.D.; Stuenkel, E.L.; Bittner, M.A. A pleckstrin homology domain specific for phosphatidylinositol 4,5-bisphosphate (PtdIns-4,5-P 2) and fused to green fluorescent protein identifies plasma membrane PtdIns-4,5-P 2 as being important in exocytosis. J. Biol. Chem. 2000, 275, 17878-17885. [CrossRef] [PubMed]

13. Martin, T.F. PI(4,5)P(2) regulation of surface membrane traffic. Curr. Opin. Cell Biol. 2001, 13, $493-499$. [CrossRef]

14. Martin, T.F.J. PI(4,5)P2-binding effector proteins for vesicle exocytosis. Biochim. Biophys. Acta Mol. Cell Biol. Lipids 2015, 1851, 785-793. [CrossRef] [PubMed]

15. Sztacho, M.; Sobol, M.; Balaban, C.; Escudeiro Lopes, S.E.; Hozák, P. Nuclear phosphoinositides and phase separation: Important players in nuclear compartmentalization. Adv. Biol. Regul. 2019, 71, 111-117. [CrossRef] [PubMed]

16. Fiume, R.; Faenza, I.; Sheth, B.; Poli, A.; Vidalle, M.C.; Mazzetti, C.; Abdul, S.H.; Campagnoli, F.; Fabbrini, M.; Kimber, S.T.; et al. Nuclear Phosphoinositides: Their Regulation and Roles in Nuclear Functions. Int. J. Mol. Sci. 2019, 20, 2991. [CrossRef]

17. Di Paolo, G.; De Camilli, P. Phosphoinositides in cell regulation and membrane dynamics. Nature 2006, 443, 651-657. [CrossRef]

18. Irvine, R.F. Thematic review series: Living history of lipids: A short history of inositol lipids. J. Lipid Res. 2016, 57, 1987-1994. [CrossRef]

19. Kooijman, E.E.E.; King, K.E.E.; Gangoda, M.; Gericke, A. Ionization properties of phosphatidylinositol polyphosphates in mixed model membranes. Biochemistry 2009, 48, 9360-9371. [CrossRef]

20. Ishihara, H.; Shibasaki, Y.; Kizuki, N.; Wada, T.; Yazaki, Y.; Asano, T.; Oka, Y. Type I phosphatidylinositol-4-phosphate 5-kinases. Cloning of the third isoform and deletion/substitution analysis of members of this novel lipid kinase family. J. Biol. Chem. 1998, 273, 8741-8748. [CrossRef]

21. Clarke, J.H.; Emson, P.C.; Irvine, R.F. Localization of phosphatidylinositol phosphate kinase IIgamma in kidney to a membrane trafficking compartment within specialized cells of the nephron. Am. J. Physiol. Renal Physiol. 2008, 295, F1422-F1430. [CrossRef] [PubMed]

22. Bunce, M.W.; Boronenkov, I.V.; Anderson, R.A. Coordinated activation of the nuclear ubiquitin ligase Cul3-SPOP by the generation of phosphatidylinositol 5-phosphate. J. Biol. Chem. 2008, 283, 8678-8686. [CrossRef]

23. De Craene, J.-O.; Bertazzi, D.; Bär, S.; Friant, S. Phosphoinositides, Major Actors in Membrane Trafficking and Lipid Signaling Pathways. Int. J. Mol. Sci. 2017, 18, 634. [CrossRef] [PubMed]

24. Liu, Y.; Bankaitis, V.A. Progress in Lipid Research Phosphoinositide phosphatases in cell biology and disease. Prog. Lipid Res. 2010, 49, 201-217. [CrossRef]

25. Dickson, E.J.; Hille, B. Understanding phosphoinositides: Rare, dynamic, and essential membrane phospholipids. Biochem. J. 2019, 476, 1-23. [CrossRef] [PubMed]

26. Bradshaw, J.P.; Bushby, R.J.; Giles, C.C.; Saunders, M.R.; Saxena, A. The headgroup orientation of dimyristoylphosphatidylinositol-4-phosphate in mixed lipid bilayers: A neutron diffraction study. Biochim. Biophys. Acta Biomembr. 1997, 1329, 124-138. [CrossRef]

27. Zhou, C.; Garigapati, V.; Roberts, M.F. Short-chain phosphatidylinositol conformation and its relevance to phosphatidylinositol-specific phospholipase C. Biochemistry 1997, 36, 15925-15931. [CrossRef]

28. Bradshaw, J.P.; Bushby, R.J.; Giles, C.C.; Saunders, M.R. Orientation of the headgroup of phosphatidylinositol in a model biomembrane as determined by neutron diffraction. Biochemistry 1999, 38, 8393-8401. [CrossRef]

29. Kishore, A.I.; Prestegard, J.H. Molecular Orientation and Conformation of Phosphatidylinositides in Membrane Mimetics Using Variable Angle Sample Spinning (VASS) NMR. Biophys. J. 2003, 85, 3848-3857. [CrossRef]

30. Hansbro, P.M.; Byard, S.J.; Bushby, R.J.; Turnbull, P.J.; Boden, N.; Saunders, M.R.; Novelli, R.; Reid, D.G. The conformational behaviour of phosphatidylinositol in model membranes: 2H-NMR studies. Biochim. Biophys. Acta 1992, 1112, 187-196. [CrossRef]

31. Slochower, D.R.; Huwe, P.J.; Radhakrishnan, R.; Janmey, P.A. Quantum and all-atom molecular dynamics simulations of protonation and divalent ion binding to phosphatidylinositol 4,5-bisphosphate (PIP 2 ). J. Phys. Chem. B 2013, 117, 8322-8329. [CrossRef] [PubMed] 
32. Brown, W.H. Organic Chemistry; Brooks/Cole Cengage Learning: Boston, MA, USA, 2009; ISBN 0495388572.

33. van Paridon, P.A.; de Kruijff, B.; Ouwerkerk, R.; Wirtz, K.W.A. Polyphosphoinositides undergo charge neutralization in the physiological $\mathrm{pH}$ range: A 31P-NMR study. Biochim. Biophys. Acta BBA Lipids Lipid Metab. 1986, 877, 216-219. [CrossRef]

34. Graber, Z.T.T.; Jiang, Z.; Gericke, A.; Kooijman, E.E.E. Phosphatidylinositol-4,5-bisphosphate ionization and domain formation in the presence of lipids with hydrogen bond donor capabilities. Chem. Phys. Lipids 2012, 165, 696-704. [CrossRef] [PubMed]

35. Björkbom, A.; Ohvo-Rekilä, H.; Kankaanpää, P.; Nyholm, T.K.M.; Westerlund, B.; Slotte, J.P. Characterization of membrane properties of inositol phosphorylceramide. Biochim. Biophys. Acta Biomembr. 2010, 1798, 453-460. [CrossRef] [PubMed]

36. D'Souza, K.; Epand, R.M. Enrichment of phosphatidylinositols with specific acyl chains. Biochim. Biophys. Acta Biomembr. 2014, 1838, 1501-1508. [CrossRef] [PubMed]

37. Traynor-Kaplan, A.; Kruse, M.; Dickson, E.J.; Dai, G.; Vivas, O.; Yu, H.; Whittington, D.; Hille, B. Fatty-acyl chain profiles of cellular phosphoinositides. Biochim. Biophys. Acta 2017, 1862, 513-522. [CrossRef]

38. Mujalli, A.; Chicanne, G.; Bertrand-Michel, J.; Viars, F.; Stephens, L.; Hawkins, P.; Viaud, J.; Gaits-Iacovoni, F.; Severin, S.; Gratacap, M.P.; et al. Profiling of phosphoinositide molecular species in human and mouse platelets identifies new species increasing following stimulation. Biochim. Biophys. Acta 2018, 1863, 1121-1131. [CrossRef]

39. Koizumi, A.; Narita, S.; Nakanishi, H.; Ishikawa, M.; Eguchi, S.; Kimura, H.; Takasuga, S.; Huang, M.; Inoue, T.; Sasaki, J.; et al. Increased fatty acyl saturation of phosphatidylinositol phosphates in prostate cancer progression. Sci. Rep. 2019, 9, 13257-13258. [CrossRef]

40. Koch, M.; Holt, M. Coupling exo- and endocytosis: An essential role for PIP 2 at the synapse. Biochim. Biophys. Acta Mol. Cell Biol. Lipids 2012, 1821, 1114-1132. [CrossRef]

41. Manni, M.M.; Tiberti, M.L.; Pagnotta, S.; Barelli, H.; Gautier, R.; Antonny, B. Acyl chain asymmetry and polyunsaturation of brain phospholipids facilitate membrane vesiculation without leakage. Elife 2018, 7, e34394. [CrossRef]

42. Nelson, D.L.; Cox, M.M. Lehninger Principles of Biochemistry Sixth Edition, 6th ed.; Macmillan Learning: London, UK, 2013.

43. Mclaughlin, S.; Wang, J.; Gambhir, A.; Murray, D. Pip(2) and Proteins: Interactions, Organization, and Information Flow. Annu. Rev. Biophy. Biomol. Struct. 2002, 31, 171-175. [CrossRef] [PubMed]

44. Golebiewska, U.; Nyako, M.; Woturski, W.; Zaitseva, I.; McLaughlin, S. Diffusion coefficient of fluorescent phosphatidylinositol 4,5-bisphosphate in the plasma membrane of cells. Mol. Biol. Cell 2008, 19, 1663-1669. [CrossRef] [PubMed]

45. van den Bogaart, G.; Meyenberg, K.; Risselada, H.J.; Amin, H.; Willig, K.I.; Hubrich, B.E.; Dier, M.; Hell, S.W.; Grubmüller, H.; Diederichsen, U.; et al. Membrane protein sequestering by ionic protein-lipid interactions. Nature 2011, 479, 552-555. [CrossRef]

46. Wang, J.; Richards, D.A. Segregation of PIP2 and PIP3 into distinct nanoscale regions within the plasma membrane. Biol. Open 2012, 1, 857-862. [CrossRef]

47. Payrastre, B.; Missy, K.; Giuriato, S.; Bodin, S.; Plantavid, M.; Gratacap, M. Phosphoinositides: Key players in cell signalling, in time and space. Cell. Signal. 2001, 13, 377-387. [CrossRef]

48. Laux, T.; Fukami, K.; Thelen, M.; Golub, T.; Frey, D.; Caroni, P. Gap43, Marcks, and Cap23 modulate Pi $(4,5)$ p2 at mlasmalemmal rafts, and regulate cell cortex actin dynamics through a common mechanism. J. Cell Biol. 2000, 149, 1455-1472. [CrossRef] [PubMed]

49. Wang, J.; Gambhir, A.; McLaughlin, S.; Murray, D. A Computational Model for the Electrostatic Sequestration of PI(4,5)P2 by Membrane-Adsorbed Basic Peptides. Biophys. J. 2004, 86, 1969-1986. [CrossRef]

50. Gambhir, A.; Hangyás-Mihályné, G.; Zaitseva, I.; Cafiso, D.S.; Wang, J.; Murray, D.; Pentyala, S.N.; Smith, S.O.; McLaughlin, S. Electrostatic sequestration of PIP2 on phospholipid membranes by basic/aromatic regions of proteins. Biophys. J. 2004, 86, 2188-2207. [CrossRef]

51. McLaughlin, S.; Murray, D. Plasma membrane phosphoinositide organization by protein electrostatics. Nature 2005, 438, 605-611. [CrossRef]

52. Rauch, M.E.; Ferguson, C.G.; Prestwich, G.D.; Cafiso, D.S. Myristoylated alanine-rich C kinase substrate (MARCKS) sequesters spin-labeled phosphatidylinositol 4,5-bisphosphate in lipid bilayers. J. Biol. Chem. 2002, 277, 14068-14076. [CrossRef] 
53. Wang, J.; Gambhir, A.; Hangyás-Mihályné, G.; Murray, D.; Golebiewska, U.; McLaughlin, S. Lateral sequestration of phosphatidylinositol 4,5-bisphosphate by the basic effector domain of myristoylated alanine-rich C kinase substrate is due to nonspecific electrostatic interactions. J. Biol. Chem. 2002, 277, 34401-34412. [CrossRef] [PubMed]

54. Dietrich, U.; Krüger, P.; Gutberlet, T.; Käs, J.A. Interaction of the MARCKS peptide with PIP2 in phospholipid monolayers. Biochim. Biophys. Acta Biomembr. 2009, 1788, 1474-1481. [CrossRef] [PubMed]

55. Tong, J.; Nguyen, L.; Vidal, A.; Simon, S.A.; Skene, J.H.P.; McIntosh, T.J. Role of GAP-43 in sequestering phosphatidylinositol 4,5-bisphosphate to Raft bilayers. Biophys. J. 2008, 94, 125-133. [CrossRef] [PubMed]

56. Aoyagi, K.; Sugaya, T.; Umeda, M.; Yamamoto, S.; Terakawa, S.; Takahashi, M. The activation of exocytotic sites by the formation of phosphatidylinositol 4,5-bisphosphate microdomains at syntaxin clusters. J. Biol. Chem. 2005, 280, 17346-17352. [CrossRef] [PubMed]

57. Murray, D.H.; Tamm, L.K. Clustering of syntaxin-1A in model membranes is modulated by phosphatidylinositol 4,5-bisphosphate and cholesterol. Biochemistry 2009, 48, 4617-4625. [CrossRef]

58. James, D.J.; Khodthong, C.; Kowalchyk, J.A.; Martin, T.F.J. Phosphatidylinositol 4,5-bisphosphate regulates SNARE-dependent membrane fusion. J. Cell Biol. 2008, 182, 355-366. [CrossRef]

59. Milosevic, I.; Sørensen, J.B.; Lang, T.; Krauss, M.; Nagy, G.; Haucke, V.; Jahn, R.; Neher, E. Plasmalemmal phosphatidylinositol-4,5-bisphosphate level regulates the releasable vesicle pool size in chromaffin cells. J. Neurosci. 2005, 25, 2557-2565. [CrossRef]

60. Shi, J.; Birnbaumer, L.; Large, W.A.; Albert, A.P. Myristoylated alanine-rich C kinase substrate coordinates native TRPC1 channel activation by phosphatidylinositol 4,5-bisphosphate and protein kinase $C$ in vascular smooth muscle. FASEB J. 2014, 28, 244-255. [CrossRef]

61. Su, R.; Han, Z.-Y.; Fan, J.-P.; Zhang, Y.-L. A possible role of myristoylated alanine-rich C kinase substrate in endocytic pathway of Alzheimer's disease. Neurosci. Bull. 2010, 26, 338-344. [CrossRef]

62. Trovò, L.; Ahmed, T.; Callaerts-Vegh, Z.; Buzzi, A.; Bagni, C.; Chuah, M.; VandenDriessche, T.; Balschun, D.; Dotti, C.G. Low hippocampal PI(4,5)P2 contributes to reduced cognition in old mice as a result of loss of MARCKS. Nat. Publ. Gr. 2013, 16, 449-455. [CrossRef]

63. Clapham, D.E. Calcium signaling. Cell 1995, 80, 259-268. [CrossRef]

64. Berridge, M.J. Calcium microdomains: Organization and function. Cell Calcium 2006, 40, 405-412. [CrossRef] [PubMed]

65. Grubbs, R.D. Intracellular magnesium and magnesium buffering. BioMetals 2002, 15, 251-259. [CrossRef] [PubMed]

66. Trapani, V.; Farruggia, G.; Marraccini, C.; Iotti, S.; Cittadini, A.; Wolf, F.I. Intracellular magnesium detection: Imaging a brighter future. Analyst 2010, 135, 1855-1866. [CrossRef] [PubMed]

67. Slochower, D.R.; Wang, Y.-H.; Radhakrishnan, R.; Janmey, P.A. Physical chemistry and membrane properties of two phosphatidylinositol bisphosphate isomers. Phys. Chem. Chem. Phys. 2015, 17, 12608-12615. [CrossRef] [PubMed]

68. Wang, Y.-H.; Collins, A.; Guo, L.; Smith-Dupont, K.B.; Gai, F.; Svitkina, T.; Janmey, P.A. Divalent cation-induced cluster formation by polyphosphoinositides in model membranes. J. Am. Chem. Soc. 2012, 134, 3387-3395. [CrossRef]

69. Ellenbroek, W.G.; Wang, Y.H.; Christian, D.A.; Discher, D.E.; Janmey, P.A.; Liu, A.J. Divalent cation-dependent formation of electrostatic PIP2 clusters in lipid monolayers. Biophys. J. 2011, 101, 2178-2184. [CrossRef]

70. Sarmento, M.J.; Coutinho, A.; Fedorov, A.; Prieto, M.; Fernandes, F. Ca2 + induces PI(4,5)P2 clusters on lipid bilayers at physiological PI(4,5)P2 and Ca2 + concentrations. Biochim. Biophys. Acta Biomembr. 2014, 1838, 822-830. [CrossRef]

71. Sarmento, M.J.; Coutinho, A.; Fedorov, A.; Prieto, M.; Fernandes, F. Membrane Order Is a Key Regulator of Divalent Cation-Induced Clustering of PI(3,5)P2 and PI(4,5)P2. Langmuir 2017, 33, 12463-12477. [CrossRef]

72. Cohen, J.A.; Cohen, M. Adsorption of monovalent and divalent cations by phospholipid membranes. The monomer-dimer problem. Biophys. J. 1981, 36, 623-651. [CrossRef]

73. Wen, Y.; Vogt, V.M.; Feigenson, G.W. Multivalent Cation-Bridged PI(4,5)P2 Clusters Form at Very Low Concentrations. Biophys. J. 2018, 114, 2630-2639. [CrossRef] [PubMed]

74. Monteiro, M.E.; Sarmento, M.J.; Fernandes, F. Role of calcium in membrane interactions by PI(4,5)P2-binding proteins. Biochem. Soc. Trans. 2014, 42, 1441-1446. [CrossRef] [PubMed] 
75. Seo, J.B.; Jung, S.R.; Huang, W.; Zhang, Q.; Koh, D.S. Charge shielding of PIP2 by cations regulates enzyme activity of phospholipase C. PLoS ONE 2015, 10, 1-22. [CrossRef] [PubMed]

76. Bilkova, E.; Pleskot, R.; Rissanen, S.; Sun, S.; Czogalla, A.; Cwiklik, L.; Rog, T.; Vattulainen, I.; Cremer, P.S.; Jungwirth, P.; et al. Calcium directly regulates phosphatidylinositol 4,5-bisphosphate headgroup conformation and recognition. J. Am. Chem. Soc. 2017, 139, 4018-4024. [CrossRef]

77. Subczynski, W.K.; Pasenkiewicz-Gierula, M.; Widomska, J.; Mainali, L.; Raguz, M. High Cholesterol/Low Cholesterol: Effects in Biological Membranes: A Review. Cell Biochem. Biophys. 2017, 75, 369-385. [CrossRef]

78. Levental, I.; Christian, D.A.; Wang, Y.-H.H.; Madara, J.J.; Discher, D.E.; Janmey, P.A. Calcium-dependent lateral organization in phosphatidylinositol 4,5-bisphosphate (PIP2)- and cholesterol-containing monolayers. Biochemistry 2009, 48, 8241-8248. [CrossRef]

79. Kwik, J.; Boyle, S.; Fooksman, D.; Margolis, L.; Sheetz, M.P.; Edidin, M. Membrane cholesterol, lateral mobility, and the phosphatidylinositol 4,5-bisphosphate-dependent organization of cell actin. Proc. Natl. Acad. Sci. 2003, 100, 13964-13969. [CrossRef]

80. Hao, M.; Bogan, J.S. Cholesterol regulates glucose-stimulated insulin secretion through phosphatidylinositol 4,5-bisphosphate. J. Biol. Chem. 2009, 284, 29489-29498. [CrossRef]

81. Epand, R.M. Proteins and cholesterol-rich domains. Biochim. Biophys. Acta Biomembr. 2008, 1778, $1576-1582$. [CrossRef]

82. Pike, L.J.; Miller, J.M. Cholesterol depletion delocalizes phosphatidylinositol bisphosphate and inhibits hormone-stimulated phosphatidylinositol turnover. J. Biol. Chem. 1998, 273, 22298-22304. [CrossRef]

83. Van Rheenen, J.; Achame, E.M.; Janssen, H.; Calafat, J.; Jalink, K. PIP2 signaling in lipid domains: A critical re-evaluation. EMBO J. 2005, 24, 1664-1673. [CrossRef] [PubMed]

84. Mu, L.; Tu, Z.; Miao, L.; Ruan, H.; Kang, N.; Hei, Y.; Chen, J.; Wei, W.; Gong, F.; Wang, B.; et al. A phosphatidylinositol 4,5-bisphosphate redistribution-based sensing mechanism initiates a phagocytosis programing. Nat. Commun. 2018, 9, 1-16. [CrossRef] [PubMed]

85. Ponuwei, G.A. A glimpse of the ERM proteins. J. Biomed. Sci. 2016, 23, 35. [CrossRef]

86. Taglieri, D.M.; Delfín, D.A.; Monasky, M.M. Cholesterol regulation of PIP2: Why cell type is so important. Front. Physiol. 2013, 3, 492. [CrossRef] [PubMed]

87. Chierico, L.; Joseph, A.S.; Lewis, A.L.; Battaglia, G. Live cell imaging of membrane/cytoskeleton interactions and membrane topology. Sci. Rep. 2014, 4, 6056. [CrossRef]

88. Johnson, C.; Rodgers, W. Spatial Segregation of Phosphatidylinositol 4,5-Bisphosphate (PIP2) Signaling in Immune Cell Functions. Immunol. Endocr. Metab. Agents Med. Chem. 2009, 8, 349-357. [CrossRef] [PubMed]

89. Nebl, T.; Oh, S.W.; Luna, E.J. Membrane cytoskeleton: PIP2 pulls the strings. Curr. Biol. 2000, 10, R351-R354. [CrossRef]

90. Zhang, L.; Mao, Y.S.; Janmey, P.A.; Yin, H.L. Phosphatidylinositol 4, 5 bisphosphate and the actin cytoskeleton. Subcell. Biochem. 2012, 59, 177-215. [CrossRef]

91. Andrade, D.M.; Clausen, M.P.; Keller, J.; Mueller, V.; Wu, C.; Bear, J.E.; Hell, S.W.; Lagerholm, B.C.; Eggeling, C. Cortical actin networks induce spatio-temporal confinement of phospholipids in the plasma membrane-A minimally invasive investigation by STED-FCS. Sci. Rep. 2015, 5, 1-12. [CrossRef]

92. Cho, H.; Kim, Y.A.; Yoon, J.Y.; Lee, D.; Kim, J.H.; Lee, S.H.; Ho, W.K. Low mobility of phosphatidylinositol 4,5-bisphosphate underlies receptor specificity of Gq-mediated ion channel regulation in atrial myocytes. Proc. Natl. Acad. Sci. USA 2005, 102, 15241-15246. [CrossRef]

93. Corbett-Nelson, E.F.; Mason, D.; Marshall, J.G.; Collette, Y.; Grinstein, S. Signaling-dependent immobilization of acylated proteins in the inner monolayer of the plasma membrane. J. Cell Biol. 2006, 174, 255-265. [CrossRef] [PubMed]

94. Botelho, R.J.; Teruel, M.; Dierckman, R.; Anderson, R.; Wells, A.; York, J.D.; Meyer, T.; Grinstein, S. Localized biphasic changes in phosphatidylinositol-4,5-bisphosphate at sites of phagocytosis. J. Cell Biol. 2000, 151, 1353-1367. [CrossRef] [PubMed]

95. Zimmerberg, J.; Chernomordik, L.V. Membrane fusion. Adv. Drug Deliv. Rev. 1999, 38, 197-205. [CrossRef]

(C) 2020 by the authors. Licensee MDPI, Basel, Switzerland. This article is an open access article distributed under the terms and conditions of the Creative Commons Attribution (CC BY) license (http://creativecommons.org/licenses/by/4.0/). 